This state of affairs was probably entirely due to lack of shelter elsewhere; it is hard to remember how unnatural for deer are conditions over most of the Highlands, the effects of the deerfence and the stalker being as unobtrusive as they are powerful. -P. Delap.

\title{
Giant Fallow Deer
}

Major Anthony Buxton, in Oryx, 1954, suggests that the fallow of Schleswig Iolstcin, and of some parts of Denmark, are "of the same type and size as the fossil horn from Clacton" which is to be seen in the Natural History Museum, South Kensington.

Whilst Dama clactoniana, which inhabited Essex during the Pleiocene period, would appear to have been very similar in size to Dama dama, the fallow of modern times, its antlers, if the pair to be secn in the British Muscum can be taken as a type specimen, would seem to be of slightly different pattern. Whereas those on Dama dama have all the jags on the posterior edge of the palmated top, Dama clactoniana had a number of strong tines on the anterior edge as well. I have seen mounted heads from Schleswig Holstein, Germany, and also the live animal in various parts of Denmark. From neither country have I seen antlers that were in any way similar to the Dama clactoniana head in the British Muscum. Whilst there is no doubt that there is a resemblance in many respects between Dama clactoniana and Dama dama, the forward tines on the upper part of the benm might also be compared to those of Megaceros hibernicus-the Giant Irish decr-but there the similarity ends.

I nm grateful to the Kecper of Geology, British Muscum of Natural History, for having sent me a photograph of the Dama clactoniana head which can be compared to the head of a good, modern Danish fallow buck and also to the antlers carried by two good bucks in Klampenborg Park, Denmark.

The illustration in Oryjx, Vol. II, No. 6, p. 392, also confirms that the fallow decr of Denmark are identical with Dama dama, with no anterior tines or jags other than the normal brow and trays. The quality of the antlers, however, is much superior to anything that can be seen in the parks of this country, although some very fine heads are grown by some of the bucks in Woburn Park.

G. KenNetil Winteiread. 